\title{
高濃度グルコース環境が乳がん細胞の動態に与える影響と亜鉛トランスポーターの役割
}

\author{
中 瀬(高谷) 朋 夏
}

\section{Migration Behavior of Breast Cancer Cells in the Environment of High Glucose Level and the Role of Zinc and Its Transporter}

\author{
Tomoka Takatani-Nakase \\ Department of Pharmaceutics, School of Pharmacy and Pharmaceutical Sciences, Mukogawa Women's \\ University; 11-68 Koshien Kyuban-cho, Nishinomiya, Hyogo 663-8179, Japan.
}

(Received June 30, 2013)

\begin{abstract}
The diabetes patients have been associated with an increased risk of mortality by breast cancer, and there are differences in the regimen choice and effects of breast cancer treatment between the breast cancer patients with diabetes and their nondiabetic counterparts. However, the pathophysiological relationships of diabetes and breast cancer have not yet been elucidated in detail, therefore its evaluation is strongly required to achieve novel treatment strategies for breast cancer with hyperglycemia. Extracellular circumstances of cancer cells can influence the growth and behavior, resulting in invasion, metastasis and tumor development. We demonstrated that breast cancer cells, MCF-7, cultured in hyperglycemic level significantly promotes the motile activity in comparison to normal physiological glucose level. Moreover, $\mathrm{Zn}^{2+}$ uptake activity into cellular cytosol and the mRNA expression of zinc transporters, ZIP6 and ZIP10, in the high glucose-exposed cells were shown to be especially higher than in the physiological glucose level. The depletion of intracellular $\mathrm{Zn}^{2+}$ by zinc chelation and ZIP6 or ZIP10 knockdown blocked the high migration activity, indicating that $\mathrm{Zn}^{2+}$ transported via ZIP6 and ZIP10 plays an essential role in the promotion of cell motility stimulated in high glucose level. These findings provide a proposing target of the novel strategies for the diagnosis and therapy of breast cancer with hyperglycemia.
\end{abstract}

Key words_— breast cancer cell MCF-7; hyperglycemia; motility; zinc; zinc transporter

\section{1. はじめに}

近年，乳がん診断時の糖尿病と死亡リスクの関連 性を検討した臨床統計学的知見において，糖尿病患 者では乳がんによる死亡リスクが有意に高く，進行 度が高い症例が多いことが示されている（Table 1). ${ }^{1-3)}$ さらに, 糖尿病の有無によりがん治療法の 選択や効果に違いがある疫学的エビデンスも得られ ている (Table 2)。1,2,4)これらの統計結果は, 糖尿 病患者において, 現在確立されている乳がん治療法 が適さない可能性を示唆し, 糖尿病併発における乳 がんの治療戦略の構築は極めて重要であると考え る.しかし，糖尿病と乳がんの病態生理学的な関係 はいまだ不明で，乳がんに対する糖尿病の影響を明

The author declares no conflict of interest.

武庫川女子大学薬学部薬剤学研究室（干663-8179 兵庫

県西宮市甲子園九番町 11-68)

e-mail: nakase@mukogawa-u.ac.jp

本総説は，平成 24 年度日本薬学会近畿支部奨励賞（医 療系薬学）の受賞を記念して記述したものである.
らかにした基礎研究はほとんどない。がんの病態 は，がん細胞の周囲の環境と深く係わっており，糖 尿病における高血糖状態ががん細胞の生育や挙動に 影響を及ぼす可能性があると予測できる。これまで 筆者らは，高血糖負荷が，がん難治化の要因である 乳がん細胞・幹細胞の造腫瘍性を六進することや, 乳がん細胞の低酸素而性能を獲得することを分子生 物学的, 生化学的に見い出し, 高血糖が乳がんの悪 性化の進展に重要な役割を担っていることを明らか にしてきた（Fig. 1)，高血糖に対する応答性を標 的とした新たな乳がんの治療戦略の開発には，高血 糖によるがん悪性化の仕組みの更なる詳細な解析が 必須である.

一方, 必須微量元素である亜鉛は, 多様な生理作 用に係わるシグナル伝達のセカンドメッセンジャー として注目されている. ${ }^{5,6)}$ その亜鉛イオン $\left(\mathrm{Zn}^{2+}\right)$ の膜透過の媒介は亜鉛トランスポーターが担い, 現 在, 哺乳類の亜鉛トランスポーターは 23 種類存在 
Table 1. The Mortality and Cancer Stage in Breast Cancer Patients with and without Pre-existing Diabetes ${ }^{1-3)}$

\begin{tabular}{lc}
\hline \hline & Hazard ratio $(95 \% \mathrm{CI})$ \\
\hline All-cause mortality & $1.20(1.07-1.35)$ \\
\hline Breast cancer-specific mortality & $1.20(1.07-1.35)$ \\
Breast cancer late stage & $1.17(1.08-1.27)$ \\
\hline
\end{tabular}

Patients with breast cancer and diabetes had a significantly higher allcause and breast cancer-specific mortality risk in comparison to their nondiabetic counterparts $(p<0.05)$. In patients with diabetes, breast cancer stage is more actively advanced than their nondiabetic counterparts $(p<0.05)$

Table 2. Diabetes and Choice of Breast Cancer Treatment ${ }^{1,2,4)}$

\begin{tabular}{lc}
\hline \hline & Odds ratio $(95 \% \mathrm{CI})$ \\
\hline Surgery & $2.32(1.01-5.38)$ \\
Hormonal therapy & $1.66(1.18-2.31)$ \\
Chemotherapy & $0.52(0.36-0.75)$ \\
Anthracyclines & $0.78(0.71-0.87)$ \\
Taxanes & $0.86(0.75-0.99)$ \\
Radiotherapy & $0.73(0.60-0.88)$ \\
\hline
\end{tabular}

Patients with breast cancer and diabetes were more likely to receive surgery and hormonal therapy than their nondiabetic counterparts $(p<$ $0.05)$.

\section{Hyperglycemic level}

\section{Adaptational response in breast cancer cells \\ Migration behavior \\ - Hypoxia and drug resistance \\ Epithelial-mesenchymal transition (EMT) induction \\ Anchorage-independent growth promotion}

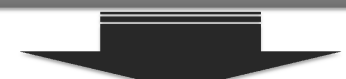

\section{Breast tumor development}

Fig. 1. The Proposed Influence of Hyperglycemic Level on Breast Tumor Development

Understanding cellular activities of breast cancer in hyperglycemic level provides a proposing target of the novel strategies for the diagnosis and therapy of breast cancer with hyperglycemia.

し, 細胞質から細胞外や細胞内小器官内の向きに亜 鉛を輸送する 9 種類の 6 回膜貫通型タンパク質であ る zinc transporter (ZnT, SLC30A family) と, 細胞 外や細胞内小器官内から細胞質の向きに亜鉛を輸送 する 14 種類の 8 回膜貫通型タンパク質である Zrt-, Irt-like protein（ZIP, SLC39A family)に大別され
る. 7) ZnT，ZIP は，セカンドメッセンジャーであ る亜鉛イオンの制御分子として，亜鉛イオンととも に重要な生理機能を担うだけでなく, 近年, ZnT, ZIP による亜鉛動態制御の破綻が疾患につながるこ とが報告されている.5,8) 特に乳がんにおいて，血清 中の亜鉛濃度は低いが，腫瘍内の亜鉛濃度は高く， ZIP ファミリーのZZIP6, 7, 10 のそれぞれが，がん の形成や悪性化に積極的に関与していることが明ら かにされてきている. ${ }^{9-12)} し$ し，これまでに，が ん患者が併発している疾病と乳がんとの関係につい て，亜鉛動態の観点から研究された報告はない。

筆者らは，高血糖状態による乳がん細胞の悪性化 進展の機構を解明するため, 乳がんにおける亜鉛卜 ランスポーターの機能と役割に着目し, 研究を続け ている．本総説では，がん悪性化の重要な因子であ る浸潤・転移に焦点を当て，糖尿病における高濃度 グルコース環境が乳がん細胞の運動性に及ぼす影響 とその調節機構に関与する亜鉛トランスポーターの 役割について，筆者らがこれまでに得た知見を中心 に紹介したい.

\section{2. 高濃度グルコース環境における乳がん細胞の} 運動能六進

高濃度グルコース環境が乳がん細胞の運動能に及 ぼす影響を検討するため，ヒト乳がん由来株細胞 MCF-7 を生体レベル（5.5 mM D-glucose） と高濃度 グルコース（25 mM D-glucose）条件下で培養し, 細胞運動性をWound assay により検討した。その 結果，高濃度グルコース処置 24 時間後，生体レベ ルのグルコース濃度で培養した群に比べて，有意に 細胞の遊走が促進した（Fig. 2)。D-glucose の代わ りに D-mannitol あるいは D-fructose を添加した浸 透圧コントロール群では, 生体レベルのグルコース 濃度と比較して, 細胞が遊走した面積に差は認めら れなかった。 さらに，運動能が促進した高グルコー ス条件下では，ラメリポディアが形成され，アクチ

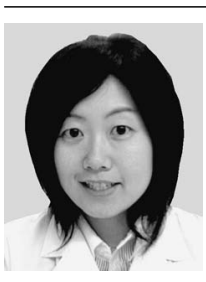

中瀬 (高谷) 朋夏
2004 年大阪大学大学院薬学研究科博士 後期課程修了. 米国パシフィックノー スウエスト研究所博士研究員などを経 て，2007 年武庫川女子大学薬学部講 師，現在に至る。臨床統計から創薬 ターゲットを, 分子細胞生物学を基盤 にしたアプローチで掘り起こし，薬剤 学・治療学で貢献できる基礎的知見の 取得や技術開発の発展を目指している。 


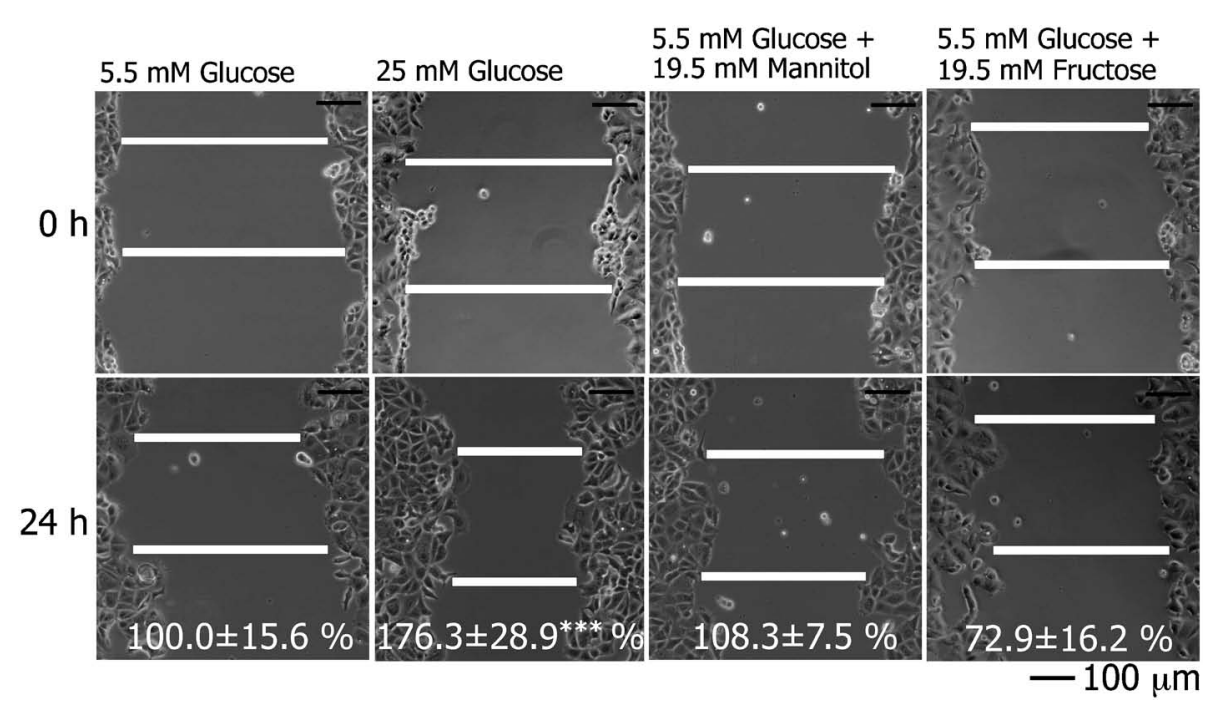

Fig. 2. Cell Migration of MCF-7 Breast Cancer Cells over a 24-h Period in Response to Hyperglycemic Level (25 mM glucose concentration) by Using the Wound Scratch Assay

The values were expressed as percentage of the wound closure area of MCF-7 cells incubated with the normal (5.5 mM) glucose concentration. Data are presented as means \pm S.D. ${ }^{* * *} p<0.001$ versus the normal and the osmotic control medium (5.5 mm glucose with $19.5 \mathrm{~mm}$ mannitol or fructose). $n=3-7$.

ン細胞骨格の再構築を伴う細胞形態変化が観察され た。これらのことから，MCF-7 は，高濃度グル コース環境と生体レベルのグルコース濃度の環境と では，乳がん細胞の動態が異なり，高濃度グルコー ス環境下において，細胞運動能を著しく克進するこ とが明らかとなった。

さらに, 高濃度グルコース環境下における細胞運 動能の亢進は，エストロジェンレセプター（ER）, プロゲステロンレセプター及び Her2 の発現が陰性 であるトリプルネガティブヒト乳がん由来細胞株 MDA-MB-231，ヒ上子宮頸がん由来細胞 HeLa 並 びにヒト前立腺がん由来細胞 DU-145 では観察され ず， ER 陽性細胞である MCF-7 に限られた。臨床 統計学的に，糖尿病を併発した乳がん患者は，糖尿 病を併発していない患者に比へ，乳がんの治療にお いてホルモン療法を受けることが有意に高いため, ER 陽性乳がんが多いことが知られている. ${ }^{4)}$ 筆者 らの結果と合わせると，ER 陽性乳がんは，高血糖 環境に対する適応能を獲得し，運動性充進といつた 悪性化進展に関与する可能性が考えられる，がん細 胞周囲の環境の違いによって, 細胞の動態が変わる ことから，浸潤・転移というアウトプットは同じで あっても，それに至るまでの機構を考慮した細胞運 動能抑制のための治療法を確立することが必要とな る.

\section{3. 乳がん細胞の動態における亜鉛と亜鉛トラン} スポーターの役割

次に, 乳がんの浸潤・転移との関連が報告されて いる亜鉛の動態が，高グルコースにより克進した細 胞運動能の調節機構に関連しているか否かを検討し た．高濃度グルコース条件下においては，生体レべ ルのグルコース濃度と比較して，MCF-7 細胞内へ の亜鉛取り込み能は有意に増加し, ZIP6 並びに ZIP10 遺伝子の高発現を認めた。さらに，亜鉛トラ ンスポーターが細胞運動性に果たす役割を明らかに するため，ZIP6，ZIP10，ZIP6 及び ZIP10に対する shRNA 発現プラスミドを導入したノックダウン細 胞を作製した。その結果，すべてのノックダウン細 胞について，コントロールベクターを導入した細胞 と比較して, 細胞内への亜鉛取り込み能が著しく減 少し, 高濃度グルコースによる細胞運動性の克進が 顕著に抑制された。また，亜鉛特異的キレート剂 $N, N, N^{\prime}, N^{\prime}$-tetrakis (2-pyridylmethyl) ethylenediamine (TPEN) の処置においても，ノックダウンの結果 と同様に，高濃度グルコース環境における運動性の 上昇は顕著に低下し，大過剩の $\mathrm{Zn}^{2+}$ の添加により 運動性が回復したことから, MCF-7 の運動性六進 に $\mathrm{Zn}^{2+}$ が必要であることが示された。 以上のこと から，乳がん細胞の高濃度グルコース環境による高 い運動能の獲得には $\mathrm{Zn}^{2+}$ が必要であり，その供給 に ZIP6 と ZIP10 が重要な役割を果たしていること 


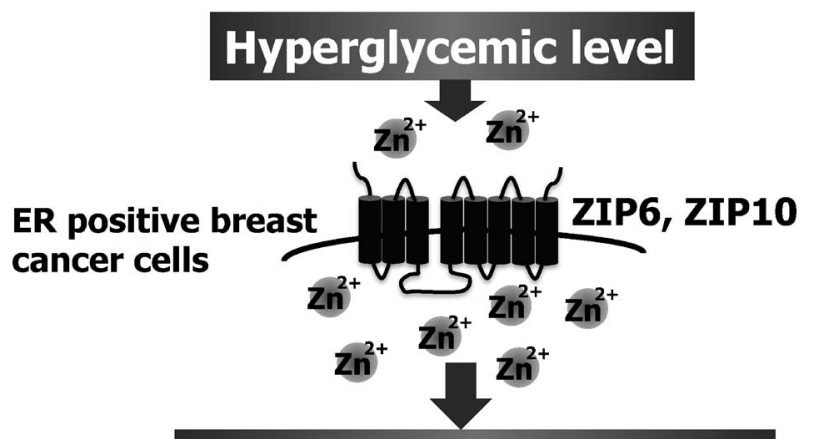

\section{Motile activity promotion}

Fig. 3. Role of ZIP6 and ZIP10 in the Promotion of Cell Motility Stimulated in High Glucose Level

を明らかとした。これまで，臨床所見において， ZIP6 はエストロゲン陽性乳がん細胞やそれを原発 巣とする細胞の転移領域において, 高い発現が認め られており,10) 本研究においても, 高濃度グルコー スによる運動能充進に ZIP6 の関与が明らかとなつ た。ZIP10については，乳がんの患者において， ZIP10 mRNA 発現がリンパ節転移陽性例において 陰性例より有意に高いことが報告されており, ${ }^{12)}$ 本 研究においても，高グルコースによる運動能克進に ZIP10 の関与が明らかとなった。ZIP6 とZIP10 は，環境要因により，その発現を巧みに変動させ， 乳がん細胞の細胞運動能充進に大きく関与している 可能性が考えられる（Fig. 3)。その機序として, 高濃度グルコース環境における, 細胞運動能と関連 した ZIP6 と 10 の機能制御機構やシグナル伝達経 路の存在が示唆されるが, ZIP の遺伝子発現制御义 カニズム, ZIP と相互作用する分子, 亜鉛感知機構, $\mathrm{ZnT}$ との関係, 細胞内に存在するメタロチオネイ ンやグルタチオンなどの亜鉛リザーバーとの関係, 他の金属イオンとの関係など，いまだ明らかにされ ておらず，その詳細は不明である。現在，筆者ら は，乳がん細胞におけるグルコース感知機構を解析 し，高濃度グルコース環境下におけるZIP6 及び ZIP10 とリンクした細胞運動能制御機構について検 討中である.

\section{4. おわりに}

筆者らは，これまでほとんど考慮されていなかつ た糖尿病併発時の乳がん治療の標的として亜鉛卜ラ ンスポーターを見い出し，これらの研究成果は，卜 ランスポーターを標的とした糖尿病併発時の乳がん
における乳がん転移能診断への応用，新たな乳がん 治療戦略への展開における重要な知見として大きく 貢献できる可能性がある。 また本研究の将来展望・ 展開として，糖尿病マウスを用いた in vivo 転移モ デルを作製し，ZIP6 及び ZIP10 ノックダウン細胞 の転移を評価することにより，糖尿病併発における 乳がん細胞の浸潤・転移における ZIP6 と ZIP10 の 役割を詳細に解明する。 さらに，糖尿病状態では， 酸化ストレスや炎症性サイトカインの産生増加が知 られており，高血糖に加え，これら因子の乳がん細 胞の動態に対する影響についても精力的に研究を進 めている。これらの研究成果を基に，高血糖環境下 における乳がん悪性化をもたらす制御機構を明らか にすることで，糖尿病併発時の乳がん診断及び治療 法確立への重要な方向性を示すことが期待される.

謝辞本研究は, 武庫川女子大学薬学部薬剂学 研究室で行われた研究であり，御指導賜りました高 橋幸一教授に心から感謝致します。また，本研究を ともに実施し，多大な御支援と御協力を頂きました 松井千紘修士，川原さと実助手，前田幸千恵助手を 始め，お世話になつた方々に深く感謝申し上げます。

\section{REFERENCES}

1) Peairs K. S., Barone B. B., Snyder C. F., Yeh H. C., Stein K. B., Derr R. L., Brancati F. L., Wolff A. C., J. Clin. Oncol., 29, 40-46 (2011).

2) Srokowski T. P., Fang S., Hortobagyi G. N., Giordano S. H., J. Clin. Oncol., 27, 21702176 (2009).

3) Fleming S. T., Pursley H. G., Newman B., Pavlov D., Chen K., Med. Care, 43, 132-140 (2005) .

4) Poll-Franse L. V., Houterman S., JanssenHeijnen M. L., Dercksen M. W., Coebergh J. W., Haak H. R., Int. J. Cancer, 120, 19861992 (2007).

5) Fukada T., Yamasaki S., Nishida K., Murakami M., Hirano T., J. Biol. Inorg. Chem., 16, 1123-1134 (2011).

6) Kambe T., Yamaguchi-Iwai Y., Sasaki R., Nagao M., Cell. Mol. Life Sci., 61, 49-68 (2004).

7) Eide D. J., Biochim. Biophys. Acta, 1763, 711 -722 (2006). 
8) Hogstrand C., Kille P., Nicholson R. I., Taylor K. M., Trends Mol. Med., 15, 101-111 (2009).

9) Gumulec J., Masarik M., Krizkova S., Adam V., Hubalek J., Hrabeta J., Eckschlager T., Stiborova M., Kizek R., Curr. Med. Chem., 18, 5041-5051 (2011).

10) Taylor K. M., Morgan H. E., Smart K., Za- hari N. M., Pumford S., Ellis I. O., Robertson J. F., Nicholson R. I., Mol. Med., 13, 396-406 (2007).

11) Taylor K. M., Hiscox S., Nicholson R. I., Hogstrand C., Kille P., Sci. Signal., 5, ra11 (2012).

12) Kagara N., Tanaka N., Noguchi S., Hirano T., Cancer Sci., 98, 692-697 (2007). 